\title{
Effectiveness of the Use of Learning Tools Based on Academics Success Skills in Achieving Cognitive Learning Indicators
}

\author{
Motlan, Jurubahasa Sinuraya and Karya Sinulingga
}

\begin{abstract}
The need for learning tools to achieve learning competencies contained in the curriculum becomes the most important thing, so it encourages Educators to continue to develop and adapt learning devices at the level of certain competencies that students are expected to have. Academic Success Skills are one of the important aspects of competency to improve graduate quality cognitively and skills in competing globally. The effectiveness of the use of learning devices it is done through observation of learning and cognitive examination results submitted to students. The test given is designed based on the Learning Outcomes listed on the learning tools used by the Lecturer with due regard to the conformity of the internalization values of the Academics Success Skills Indicators. Tests are given at 5 different courses and 5 classes in one semester. The Academic Success Skills indicator is used as an important standard as a basis for determining the level of ability of graduates to be able to fight in life globally. Graduates' readiness can be seen from the high ability achieved through the cognitive tests submitted. The results achieved from cognitive testing from the results of a gradual testing conducted on 178 students concluded that there was an increase in the effectiveness of learning outcomes by 65 percent of the total; with the criteria of 74 Students in the Low Group (Increase of 1 to 20 percent), 35 Students in the Middle Group (Increase of 21 to 39 percent), and 7 Students in the High Group (Increase of 40 to 100 percent).
\end{abstract}

Keywords-Learning Tools, Academics Successful Skills Indicator, Cognitive Test, Learning Outcomes.

\section{INTRODUCTION}

Improvement the learning tool is one of the improvements in learning done by Educators. Information and Clarity is the most important thing as a basis for presenting the latest updates on the advancement of science and technology. Various ways have been done by changing teaching techniques, learning models, the use of media and teaching materials with the latest information in order to optimize learning in learning outcomes. Competency developments based on the KKNI require the University to produce graduates of a certain level to be able to compete globally through the formulation of Learning Outcomes set by the Ministry. The standard level of graduates is

This work was supported in Indonesian DRPM through the BOPTN Fund, Universitas Negeri Medan, Universitas Quality, and Universitas Quality Berastagi.

Motlan. Universitas Negeri Medan, Medan 20221, Indonesia

Jurubahasa Sinuraya. Universitas Negeri Medan, Medan 20221, Indonesia

Karya Sinulingga. Universitas Negeri Medan, Medan 20221, Indonesia adjusted to the level of education undertaken.

The design of learning tools is directed based on graduate profiles owned by agencies by developing Graduate Learning Outcomes. Achievement of learning is an operational learning goal that is overall a target of achievement in preparing graduates. Graduates produced are expected to have a graduate profile that can be used as a reference in conformity in the specific of job.

Improvement of learning tools by internalizing various media and learning strategies is becoming a research trend at the university level, especially in Indonesia. Various improvements aim at improving learning outcomes and perfecting the application of learning strategies [1]-[6]. Improvement of learning tools can be in the form of learning planning, media implementation, learning assessment, and the development of a college curriculum. Improvements that have been made show the results of improved learning outcomes [7]-[15]. Nevertheless, the increase in learning outcomes in the form of an increase in cognitive abilities is only in the form of calculations and solving factual problems. Submission of problems submitted in the form of tests is considered not yet able to meet the learning outcomes to achieve graduate profile [14], [16]-[19]. The consequences for graduates do not have the competencies that should be possessed in the profile of graduates. Thus, graduates produced do not have the skills that can be used to achieve success in real life.

Achievement of graduates having Academic success skills can direct success in carrying out work that is in accordance with the graduate profile [13], [16], [18]-[22]. This can happen if in the planning of teaching and learning tools internalize Academic success skills in learning. Internalizing Academic success skills can be identified during learning. Identification is done to show whether or not there are indicators of Academic success skills for students. Indicators of Academic success skills can be cognitively internalized. Internalization is done with a higher order thinking approach. This approach makes students think to be able to develop themselves in achieving success in everyday life [3], [6], [23]-[27]. The ability to think and plan by internalizing Academic success skills can direct the results of thinking on the maximum achievement that can be achieved. Thus, students have the skills and abilities to achieve success.

Internalized academic success skills indicators are cognitively adapted to procedural and metacognition knowledge. Both pieces of knowledge are based on the level of 
Applying, Analyzing, Evaluating, and Create. Based on these levels, the test given as an indicator of assessing cognitive abilities resulting from internalization with Academic success skills has represented learning activities in terms of ability and skill. These abilities and skills illustrate the profile of graduates who are able to compete globally. Academic success skills indicators that are cognitively internalized are Risk-taking and Metacognition. Both indicators are descriptions of Academic success skills as supporting the thinking process.

The balance between Academic success skills and cognitive abilities internalized in the preparation of learning tools makes learning outcomes more effective in achieving a profile of graduates who have skills and abilities that are reliable and build success in graduates [1], [9], [28]-[31]. The characteristics of these graduates are able to compete globally and achieve optimal results in all respects. The indicators shown by graduates in achieving optimal results are the basis of the application of learning that internalizes Academic success skills indicators. Optimal achievement is the effect of the results achieved from systematically implemented planning [2], [4], [5], [7]-[10], [21], [24], [26]. Thus, planning that has been made can produce effectiveness at the objectives achieved.

\section{METHOD}

The Test Skills Indicators are listed on learning tools. Tests are given at 5 different courses and 5 classes in one semester. Tests are based on Taxonomy Bloom-Anderson for Applying, Analyzing, Evaluating, and Create in procedural and metacognition knowledge. The Academic Success Skills indicator is used as an important standard as a basis for determining the level of ability of graduates. Tests arranged are internalized with Academic success skills (Risk-taking and Metacognition) indicators. Graduates' readiness can be seen from the high-ability cognitive tests submitted. The sample is 178 students. The sample underwent a test and was divided based on the Gain from the pretest and posttest. Division based on Decrease Gain; Static Gain; and Gain Increase. The effectiveness of the use of learning tools based on academic success skills in achieving cognitive learning indicators can be seen through the Gain Increase percentages obtained. The percentage of Gain Increase is divided into 3 groups (Low; Middle; High). The division of this group is divided based on the number of increases in the percentage of the gain obtained.

\section{RESUlT AND DisCUSSION}

The results of cognitive testing from the results of gradual testing conducted on 178 students are shown in Fig. 1 and Fig. 2. The results are interpreted using descriptive statistics. Calculations illustrate the percentage of the number of Students. This information shows the difference in Gain acquisition between groups. Retrieval of score data based on cognitive exam results by using Taxonomy Bloom and Anderson indicators which are associated with Academic Success Skills indicators. Score data were analyzed by considering the Gain level through the pretest and posttest. The difference between the two scores describing Student was in the Decrease, Static, or Increase groups.

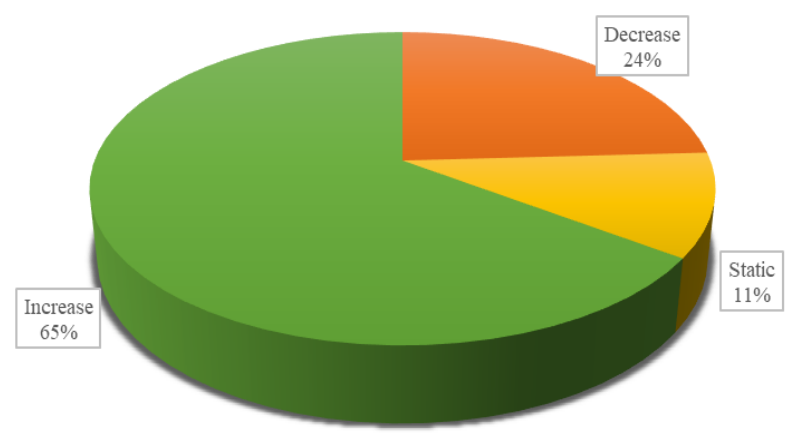

Fig. 1. Division of Groups based on Gain

The calculation of the gain shows that the majority of Gain increases by $65 \%$. Students in the group increased by 116 from 178 students. This shows that the application of learning tools based on academic success skills in learning is very effective to use. This effectiveness is based on an academic increase in thinking ability. The thinking ability of students is trained by using learning tools based on academic success skills to be able to develop with various solutions to the problems that have been proposed. The development of thinking skills encourages students to be more creative in providing solutions and alternative problem solving [11], [12], [14], [16], [21], [25], [26], [32].

The use of learning tools based on academic success skills in learning has provided assistance to students in understanding and applying them. Students are directed through procedural learning activities and problems that stimulate curiosity to find various information as an alternative solution. Various learning experiences experienced form the personality of students to be able to succeed in the work that will be undertaken in accordance with the profile of graduates [2], [4], [7], [8], [23]. Thus, the success of universities in producing graduates who have the ability and skills in accordance with the profile of graduates is more effective with learning tools based on academic success skills.

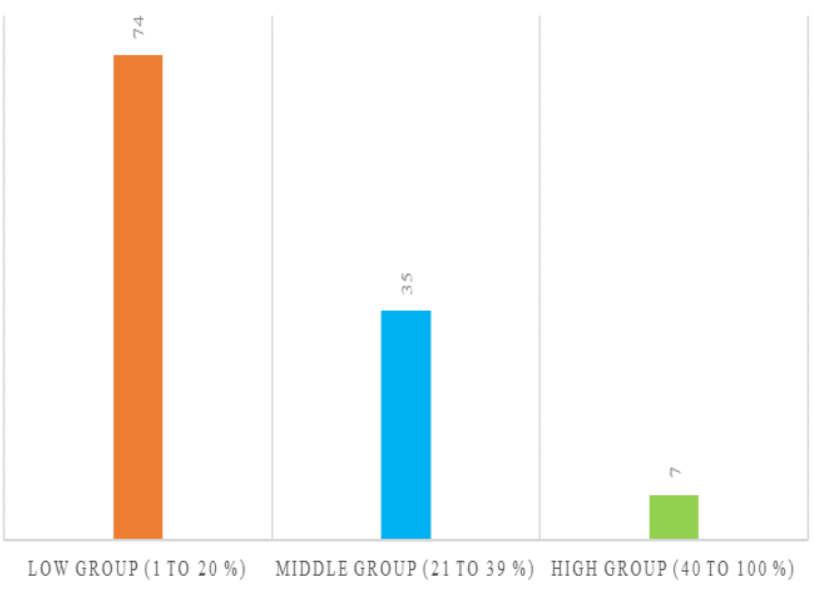

Fig. 2. Total Student in Increase Group Gain percentage 
Based on Fig. 2. The results achieved from cognitive testing are conducted on 178 Students concluded that there is an increase in the effectiveness of learning outcomes by 65 percent of the total; with the criteria of 74 Students in the Low Group (Increase of 1 to 20 percent), 35 Students in the Middle Group (Increase of 21 to 39 percent), and 7 Students in the High Group (Increase of 40 to 100 percent). These variations in differences are based on differences in the level of cognitive abilities. The high group is a group with higher Gain and achieves higher metacognition abilities. The increase achieved is located in the Low group not reaching more than $20 \%$. This is because 74 out of 116 Students are only able to solve problems with the level of Applying and Analysis at the stage of procedural knowledge. The majority of the increase in the Low group is because learning is usually done through the experimental stage and problems referring to the picture.

The ability of metacognition achieved by Students through cognitive tests is still relatively low. This is proven by the small number of Students who are able to have metacognition knowledge indicators. This is because the majority Student thinking process is still in procedural knowledge. However, by using learning tools based on academic success skills Students' abilities can increase. This increase is owned by Students by familiarizing themselves with the use of learning tools based on academic success skills. Students are trained in developing thoughts to be able to achieve metacognition knowledge [3], [6], [8], [13], [18], [19], [25], [26], [33]. By having metacognition knowledge, Students can achieve success in planning and various considerations taken to live life. Therefore, the use of learning tools based on academic success skills is needed to be done repeatedly and applied to become a standard and better improvement results [4], [5], [12], [16], [17], [21], [22], [25].

\section{CONCLUSION}

The use of Learning Tools Based on Academic Success Skills may not succeed in fully improving cognitive learning. However, the results of the data showed that $65 \%$ of the sample had increased. This proves that the use of Learning Tools Based on Academic Success Skills is still quite effective to be used and applied as the development of cognitive learning for students. This increase was marked by the criteria of 74 Students in the Low Group (Increase of 1 to 20 percent), 35 Students in the Middle Group (Increase of 21 to 39 percent), and 7 Students in the High Group (Increase of 40 to 100) percent). However, the mechanism of application, current results indicate that the use of Learning Tools Based on Academic Success Skills can improve cognitive learning. With ongoing treatment and conducted on various courses, the Student will truly achieve Academic Success Skills with high thinking skills.

\section{ACKNOWLEDGMENT}

The authors would like to thank DRPM for funding this research with the BOPTN Fund in 2017 to 2019. Thanks also for the collegial input and discussion of knowledgeable
Research Teams (Universitas Negeri Medan) and Partners (Universitas Quality and Universitas Quality Berastagi) and their assistance in the smooth running of the project, especially in expert meetings and summarizing feeds turn back.

\section{REFERENCES}

[1] T. M. Kelley, "Neo-cognitive learning theory: Implications for prevention and early intervention strategies with at-risk youth," Adolescence, vol. 28, no. 110, pp. 439-460, 1993.

[2] L. M. Ruban, D. B. McCooach, J. M. McGuire, and S. M. Reis, "The differential impact of academic self-regulatory methods on Academic Achievement Among University Students With and Without Learning Disabilities," J. Learn. Disabil., vol. 36, no. 3, pp. 270-286, 2003. https://doi.org/10.1177/002221940303600306

[3] G. V. Caprara, M. Vecchione, G. Alessandri, M. Gerbino, and C. Barbaranelli, "The contribution of personality traits and self-efficacy beliefs to academic achievement: A longitudinal study," Br. J. Educ. Psychol., vol. 81, pp. 78-96, 2011. https://doi.org/10.1348/2044-8279.002004

[4] L. Graham, A. Bellert, J. Thomas, and J. Pegg, "QuickSmart : A Basic Academic Skills Intervention for Middle School Students with Learning Difficulties," J. Learn. Disabil., vol. 40, no. 5, pp. 410-419, 2007. https://doi.org/10.1177/00222194070400050401

[5] I. C. Kongerud and P. O. Vandvik, "Work files as learning tools in knowledge management," Tidsskr Nor Legeforen $n r$, vol. 15, pp. 1587-1590, 2013. https://doi.org/10.4045/tidsskr.12.1441

[6] S. Ghavifekr and W. A. W. Rosdy, "Teaching and Learning with Technology: Effectiveness of ICT Integration in Schools Teaching and Learning with Technology: Effectiveness of ICT Integration in Schools," Int. J. Res. Educ. Sci., vol. 1, no. 2, pp. 175-191, 2015. https://doi.org/10.21890/ijres.23596

[7] P. Mesaros, M. Mesarosova, and M. L'udmila, "Learning to Learn Competency, Metacognitive Learning Strategies and Academic Self-Concept of University Students," Int. J. Arts Sci., vol. 5, no. 2, pp. 489-497, 2012.

[8] C. F. B. Murphy, D. R. Moore, and E. Schochat, "Generalization of Auditory Sensory and Cognitive Learning in Typically Developing Children," P ONE, vol. 10, no. 8, pp. 1-17, 2015. https://doi.org/10.1371/journal.pone.0135422

[9] J. Musch and A. Broder, "Test anxiety versus academic skills : A comparison of two alternative models for predicting performance in a statistics exam," Br. J. Educ. Psychol., vol. 69, pp. 105-116, 1999. https://doi.org/10.1348/000709999157608

[10] J. R. Nelson, G. J. Benner, S. Neill, and S. A. Stage, "Interrelationships Among Language Skills, Externalizing Behavior, and Academic Fluency and Their Impact on the Academic Skills of Students With ED," J. Emot. Behav. Disord., vol. 14, no. 4, pp. 209-216, 2006. https://doi.org/10.1177/10634266060140040401

[11] D. M. Kamps et al., "Curriculum Influences on Growth in Early Reading Fluency for Students with Academic and Behavioral Risks: A Descriptive Study," J. Emot. Behav. Disord., vol. 11, no. 4, pp. 211-224, 2003. https://doi.org/10.1177/10634266030110040301

[12] J. Dunlosky, K. A. Rawson, E. J. Marsh, M. J. Nathan, and D. T. Willingham, "Improving Students' Learning With Effective Learning Techniques : Promising Directions From Cognitive and Educational Psychology," Psychol. Sci. Public Interes., vol. 14, no. 1, pp. 4-58, 2013. 
https://doi.org/10.1177/1529100612453266

[13] M. E. Alvarez and A. J. Frey, "Promoting Academic Success through Student Engagement," Child. Sch., vol. 34, no. 1, pp. $1-2,2012$. https://doi.org/10.1093/cs/cdr005

[14] R. Lyons, T. R. Johnson, M. K. Khalil, and J. C. Cendan, "The impact of social context on learning and cognitive demands for interactive virtual human simulations," PeerJ, pp. 1-21, 2014. https://doi.org/10.7717/peerj.372

[15] O. Y. Tektas et al., "Digit ratio ( 2D : 4D ) and academic success as measured by achievement in the academic degree ' Habilitation ," P ONE, vol. 14, no. 2, pp. 1-17, 2019. https://doi.org/10.1371/journal.pone.0212167

[16] I. A. V. Yandari, H. Nindiasari, E. Khaerunnisa, A. S. Pamungkas, Karso, and Nurjannah, "Self-Regulated Learning in Designing Explorative Learning Tools Among Mathematics Pre-service Teachers through Explorative Module," in SHS Web of Conferences, 2018, vol. 42, pp. 1-7. https://doi.org/10.1051/shsconf/20184200106

[17] M. E. Logue, "Early Childhood Learning Standards : Tools for Promoting Social and Academic Success in Kindergarten," Child. Sch., vol. 29, no. 1, pp. 35-43, 2007. https://doi.org/10.1093/cs/29.1.35

[18] L. M. D. Huckbay, "The Effect of Creating a Mental Set on Cognitive Learning and Affective Behaviors of Nursing Student," Nurs. Forum, vol. 44, no. 4, pp. 222-234, 2009. https://doi.org/10.1111/j.1744-6198.2009.00148.x

[19] D. K. Housman, "The importance of emotional competence and self - regulation from birth : a case for the evidence - based emotional cognitive social early learning approach," Int. J. Child Care Educ. Policy, vol. 11, no. 13, pp. 1-19, 2017. https://doi.org/10.1186/s40723-017-0038-6

[20] M. Good and G. R. Adams, "Linking Academic Social Environments , Ego-Identity Formation , Ego Virtues And Academic Success," Ad, vol. 43, no. 170, pp. 221-236, 2008.

[21] M. A. Wainwright, M. J. Wright, M. Luciano, G. W. Montgomery, G. M. Geffen, and N. G. Martin, "A Linkage Study of Academic Skills Defined by the Queensland Core Skills Test," Behav. Genet., vol. 36, no. 1, pp. 56-65, 2006. https://doi.org/10.1007/s10519-005-9013-z

[22] S. Byun and H. Park, "The Academic Success of East Asian American Youth: The Role of Shadow Education," Sociol. Educ., vol. 85, no. 1, pp. 40-59, 2012. https://doi.org/10.1177/0038040711417009

[23] R. L. Brown, "Using Learning Strategy Instruction To Promote English Language Students ' Academic Success," Int. J. Arts Sci., vol. 6, no. 2, pp. 91-101, 2013.

[24] A. S. Preston, S. C. Heaton, S. J. McCann, W. D. Watson, and G.
Selke, "The Role of Multidimensional Attentional Abilities in Academic Skills of Children With ADHD," J. Learn. Disabil., vol. 42, no. 3, pp. 240-249, 2009. https://doi.org/10.1177/0022219408331042

[25] M. Gettinger and J. K. Seibert, "Contributions of Study Skills to Academic Competence," School Psych. Rev., vol. 31, no. 3, pp. 350-365, 2002.

[26] E. A. Haapala et al., "Associations of Physical Activity and Sedentary Behavior with Academic Skills - A Follow-Up Study among Primary," PLoS One, vol. 9, no. 9, pp. 1-12, 2014. https://doi.org/10.1371/journal.pone.0107031

[27] H. Nindiasari, I. A. V. Yandari, E. Khaerunnisa, and A. S. Pamungkas, "The Skill in Designing Explorative Learning Tools Of Mathematics Pre-Service Teachers Through Explorative Learning Based On Metacognitive Scaffolding," in SHS Web of Conferences, 2018, vol. 42, pp. 1-7. https://doi.org/10.1051/shsconf/20184200105

[28] E. M. Pothos and J. R. Busemeyer, "Can quantum probability provide a new direction for cognitive modeling ?," Behav. Brain Sci., vol. 36, pp. 255-327, 2013. https://doi.org/10.1017/S0140525X12001525

[29] G. Bleser et al., "Cognitive Learning, Monitoring and Assistance of Industrial Workflows Using Egocentric Sensor Networks," $P$ ONE, vol. 10, no. 6, pp. 1-41, 2015. https://doi.org/10.1371/journal.pone.0127769

[30] A. Ceccarelli, A. M. Rocca, E. Pagani, A. Falini, G. Comi, and M. Filippi, "Cognitive learning is associated with gray matter changes in healthy human individuals: A tensor-based morphometry study," Neuroimage, vol. 48, pp. 585-589, 2009. https://doi.org/10.1016/j.neuroimage.2009.07.009

[31] M. F. del Río and K. Strasser, "Preschool Children 's Beliefs about Gender Differences in Academic Skills," Sex Roles, vol. 68, pp. 231-238, 2013. https://doi.org/10.1007/s11199-012-0195-6

[32] A. M. Kaba and Y. Talek, "Self-Concept And Academic Success Among University Students," Int. J. Arts Sci., vol. 8, no. 1, pp. 89-102, 2015.

[33] B. E. Wexler et al., "Cognitive Priming and Cognitive Training: Immediate and Far Transfer to Academic Skills in Children," Nat. Publ. Gr., no. September, pp. 1-10, 2016. https://doi.org/10.1038/srep32859 